Let us now follow this treatment, that we may ascertain its final fate. I shall, for this purpose, report the opinions of a few surgeons who either employed it themselves or were familiar with its use.

Peter Massuet defended Verduin's method on account of the marvellous rapidity with which the stump healed and on account of the certainty with which the flow of blood ras controlled by the pressure over the flap. Lorenz Heister, born at Frankfort-on-the-Main in 1682, died April 19th, 1758, and in 1719 was Professor of Surgery at Helmstadt, condemned this method, particularly on the ground that the flap was too much irritated by the projection of the bone, thereby giving rise to pain and inflammation. He strongly urged the use of ligatures.

Johann Ludwig Petit, born 1674, died 1750, professor and director of the Surgical Academy of Paris, endeavoured to produce compression of the vessels by a new instrument, which covered the stump in the same manner as Verduin's Retenaculum, but was worked by a screw. He remarked that the objection to Verduin's method was that it was occasionally followed by gangrene.

Thom. Ren. Gagnier attempted to show that Verduin's method was known to the ancients; he supposed that Celsus practised in accordance with it. $\mathrm{He}$ also recommended the ligature instead of Petit's compression for the arrest of hæmorrhage.

Hugo Ravatou and Vermule recommended as an improvement to Verduin's method two flaps instead of one. Garengeot improved Verduin's method by the use of the ligature instead of the retenaculum, applying to the stump compresses and bandages, and afterwards placing it on a pillow. The objections urged against Verduin's method, and which finally led to its being abandoned, were that the compression required to control the hrmorrhage gave rise in some instances to severe pain, in others to inflammation and gangrene.

$$
\text { I am, Sir, yours truly, }
$$

B. A. Watson, M.D.,

Jersey City, N.Y., U.S.A. Surgeon to Jersey City Charity, and

\section{"PLAGUE IN RUSSIA."}

To the Editor of THE LANCET.

SIR,-I was much astonished when reading in your journal (The LANCET of February 15th, 1879, p. 238) an article on "Plague in Russia : a Retractation." Your reporter has based his conclusions on a report of the medical department of the Russian Ministry of the Interior for the year 1877; but it is very unfortunate that his conclusions are based on the facts wrongly interpreted or misunderstood. He says that in 1877, 241 cases of Siberian plague (peste de Siberie, as the Russians designate bubonic plague) were reported to the imperial medical authorities. But the Siberian plague (pustula maligna, or carbunculus malignus) is not the bubonic plague observed at Astrakhan. The Russians designate by the name Siberian plague, or Siberian ulcer (Sibirstiaja jasuce) the disease that occurs not rarely among horses and cows, and is also infective for man; but among men this disease has not an epidemic character, but comes only by way of infection from diseased cattle, and is characterised by formation of carbuncules or pustules on various parts of the body, but especially on the face, hands, and feet, generally on the parts more exposed to infection from the exterior, or by inoculation of virus from diseased animals. Among men the malady is not very dangerous, as you can see from the percentage of mortality, that reaches the number of 21 per cent. The Siberian plague. or ulcer, comes not rarely, especially among horses, in many, but more commonly in eastern and northern provinces of the Russian empire, in marshy localities. By many authors the origin of the malady is ascribed to unhealthy evaporations from marshes during hot summer weather. The rases of Siberian ulcer among men occur also especially during the warmer months of summer, and they originate from infection from cattle. I have myself observed this disease in the province of Twer among horses; the disease was very fatal, and I have heard also of many cases of death among peasants. Among our rural population the opinion prevails that the ulcer or carbunculus is developed in man by means of a bite by an infected fly that had sucked the blood of a diseased animal ; and perhaps this opinion is not wrong. All the cases occurring among men have not had an epidemic character, and occurred in villages far distant one from another; although it is obvious that the Siberian plague, or ulcer, is a disease quite distinct from bubonic plague, or pestis indica, as the last is described in the report of Dr. Döppner, translated in THE LANCET for Feb. lst. If you accept that the Siberian plague is identical with common plague you must say that the plague is a malady very common in Russia, and that it exists there at all times; but it is not true. The last epidemic plague described in the province of Astrakhan is a true bubonic Asiatic plague, that extended from Persian limits by the way of the Caspian trade. I shall be very happy if you take ny note as a correction of an involuntary mistake made by your honourable referent. The notions concerning the Russian Empire are so imperfect in your country that it is no wonder that such a mistake has been made. It would be more desirable that the Russian medical department should publish an official note, announcing that the Siberian plague observed in 1877 is not a malady lately prevalent in Astrakhan, and has no connexion with it.

I beg pardon, Sir, for my incorrect English, but my intention is only to correct the mistake, when the question of the plague has an importance for all Europe, and we are probably near to its complete disappearance from the limits of Russia.

Your obedient servant,

N. BARESKOFF

Sterlitamak, Province of Uffa, A rsiano-Petrovsky Ironfoundry. March 11 (23), 1879.

** We have to thank our correspondent for his very interesting letter. Our information was derived from what we believed to be a trustworthy Russian source, in which the meaning we adopted was attached to the term "Siberian plague." It is a pity that a loose phrase of this sort should be made use of by professional writers when a correct technical term can be substituted for it.-ED. L.

\section{DEAF-MUTISM.}

\section{To the Editor of THE LANCET.}

SrR,-Not long ago I was consulted as to the mental condition of a child, and learnt the following family history, which is not without general interest, I think.

The father of the child was at the time I refer to aged forty-seven, and the mother forty-two. They were not related to one another, and they were both steady, sober, and healthy persons. They had had seven children. Nos. 1 and 2 were boys, and the third was a girl, all healthy. Nos. 4, 5, and 6 were girls, and were all born deaf and dumb. No. 7, a girl, was healthy, and was, when I was consulted, twenty-one months old.

I failed to discover any clue to the anomalons condition of the three deaf and dumb children. There certainly was no evidence of syphilis. The first-born of the deaf-mutes was intelligent and acquired knowledge, and got a prize at the village school for sewing and writing, showing some natural aptitude. The child brought to me was eight years old, and seemed intelligent, but was rather irritable, and had been teased by other children apparently. I did not consider her defieient in her mind, and advised her being educated and protected from annoyance.

I ām, Sir, yours obediently,

$$
\text { G. MACKENzIE BACON, M.A., M.D. }
$$

Cambs. Asylum.

\section{CASE OF BILIARY CALCULI.}

\section{To the Editor of THE LANCET.}

Sir,-Some months ago I communicated to you a case of over two thousand biliary calculi, and which you inserted in your columns last July. Since then I have met with another case, which perhaps you may deem worthy of a very short notice. Like the former, it occurred in a female, S. B-, aged fifty-six years. The gall-bladder, which was of natural size, contained nearly an ounce and a half of very viscid, blackish-coloured bile, of a somewhat fetid 